\title{
CLÁUDIO PERANI
}

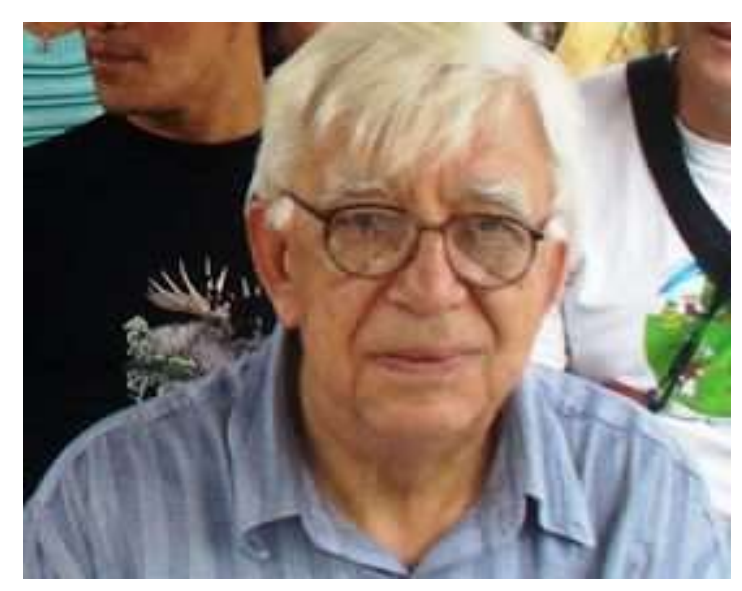

Há dez anos, passava por Manaus, quando soube da morte, aos setenta e seis anos, do Pe. Cláudio Perani, jesuíta que eu conhecia das Assembleias do Regional Norte I da Conferência Nacional dos Bispos do Brasil. Desde a primeira vez que o vi, fiquei impressionado. Homem culto, sóbrio, radical em suas colocações, comprometido com os pobres e com os movimentos de libertação, sonhador e cheio de esperança, tinha um olhar que transmitia paz e ternura. Aos poucos, fui conhecendo sua biografia e suas convicções teológicas. Quando veio para Manaus, para ser o primeiro superior do grupo de jesuítas que aqui se instalara, já tinha um histórico de compromisso com os pobres que o tinha levado a ser perseguido pela ditadura militar.

A notícia de seu falecimento me pegou de surpresa. Tive a sensação de que alguns projetos e sonhos dele entrariam numa nova fase ou não resistiriam. Ao menos três me vieram a mente: o SARES, a CPT e a equipe itinerante. Participei da missa de corpo presente e depois acompanhei o cortejo até o cemitério. Até hoje me lembro da simplicidade da liturgia eucarística e dos ritos finais junto à sepultura. Nunca antes eu participara de um ritual em que as palavras previstas correspondiam tanto à vida e ao mistério que estávamos celebrando.

* Publicado originalmente em O Jornal em Tempo, em 12 de agosto de 2018. Fonte: https://arquidiocesedemanaus.org.br/2018/08/13/claudio-perani/. Manaus, 13 de agosto de 2018. 
A Palavra proclamada foi vivida pelo Pe. Cláudio de forma intensa. Quantos retiros fez e orientou na vida. Era um mestre do discernimento. Ele fez parte de uma geração de ouro que ou já partiu para a casa do Pai, como foi o caso do Pe. João Sucarrats, salesiano, ou já se retirou do campo de batalha, devido à idade e à doença, como o Pe. Guidoti.

Eram homens apaixonados pela Igreja e fiéis a ela, não de forma teórica e idealista, mas enraizados na Igreja local. E, na última etapa de sua vida, ele descobriu a Amazônia e seu povo. Celebrar os dez anos de sua partida não pode resumir-se a homenagens, pois tenho certeza de que ele as dispensaria. Mas já é tempo de olhar onde estamos e o que fizemos dos seus sonhos. No fundo, queremos e devemos nos perguntar se somos fiéis a Jesus e se nossa Igreja é um sinal de esperança para os humilhados da terra. No dia das suas exéquias, eu tinha a certeza de que ele entrara no Reino que desejara tanto que acontecesse já aqui na terra. $\mathrm{A}$ Igreja existe para que o Reino aconteça no espaço e no tempo. Quando o Reino definitivo acontecer, não teremos mais necessidade de mediações e mediadores. Mas, enquanto caminhamos neste mundo, Deus envia profetas que abrem caminhos. Cláudio Perani foi um desses enviados.

Hoje vivemos outros tempos, mas a pobreza, a miséria e a exclusão de tantos seres humanos continuam a desafiar nossa fé e nossa razão. Não podemos ser ingênuos e é necessário conhecer os mecanismos da morte e da vida. A capacidade de resistência do humano pode nos surpreender. É preciso levar a sério o que vem dos pobres, ouvir suas histórias, conhecer sua cultura, raspar a tinta da opressão que durante muito tempo gerou o silêncio e a dor. Os jesuítas da Amazônia são os guardiães deste legado que também pertence à Igreja de nossa região. Fazer memória é tornar presente. Uma presença que interpela e leva à conversão.

\footnotetext{
** Arcebispo Metropolitano de Manaus.
} 